\title{
FILSAFAT ILMU DALAM PENGEMBANGAN ILMU AGAMA ISLAM: Menuju Kualitas Sarjana Muslim
}

\section{Mohammad Asrori}

Fakultas Tarbiyah Universitas Islam Negeri Malang, Jl. Gajayana 50. Malang 65144 Telp. 0341551354,08165461026. omail: Asroobadali@ yahoo.com

\section{Abstract}

In the Moslem Era people lost their basic of epistemology. Their thought has inflexibly normative and dogmatized. It is just like to understand their doctrine on the real texts. Memorizing and practicing their religious rituals has become only'for doing the formality. They, then, depending on the new science, excavating of the research, and understanding of the Quran and Sunnah contextually is closely ignored. Moreover, in understanding the essentialism value of their teaching is inclined a priori apologetic, exclusively lack of interaction and dialogue with the philosophy, such as nowadays' development on sciences. Because of that, the existence of philosophy can inspire the Muslims academician to be awate of being Muslims humanity by philosophy-methodologyempiricism-rationalism approach as well as to come into being dialogue interaction culture with various approaches of theology, sociology, empiricism, history, anthropology, positivism, etc. Those have been grown in this world, hence, it can turn up many academicians as scientists around us.

Key words: philosophical science, Islamic religion, epistemology

Ulul Albab, Vol. 10, No. 1, 2009 


\section{Pendahuluan}

Filsafat merupakan suatu metode (cara), sarana, perantara (wasilah), atau jalan (thariqah) menuju suatu proses dalam mencari hakekat kebenaran, bukan berarti suatu upaya menuju proses dalam mencari tujuan (al-ghayah wa al-hadaf) kebenaran itu sendiri. Boleh jadi, kebenaran yang dimaksud adalah, sebagai kebenaran plural yang meliputi (1). korespondensi, (2). emperistik, (3). hermeneutik, (4). rasionalistik, (5). subtansialistik, dan (6). koherensi.

Persoalan ilmu'dapat dilihat dari berbagai sudut pandang, sebagaimana ilmu dalam perspektif Islam, dan ilmu dalam perspektif sosio-historis. Melihat dari polarisasi sudut pandang tersebut, sesungguhnya akan dapat melahirkan substansialisme pemahaman makna ilmu yang sebenarnya secara komprehenship sebagaimana yang kita harapkan.

Selanjurnya, para sarjana Muslim dalam pola pengembangan agama Islam diharapkan dapat memberikan berbagai interpretasi pada ruang lingkup kerangka apa yang terkandung dalam ajaran-ajarannya sedemikian rupa, sehingga pemahaman yang dimaksudkan masih dapat sejalan dengan tuntutan perkembangan situasi dan kondisi sampai saat ini. Oleh karena itu, sejauh mana filsafat ilmu itu dapat dijadikan pola pengembangan agama Islam? Dapatkah filsafat ilmu dijadikan pengembangan keilmuan oleh para sarjana Muslim? Bagaimana penerapannya?

Bertolak dari pernyataan di atas, setidaknya dapat dicoba memulai dan memformulasikan hasil kontemplasi persoalan yang ada korelasinya dengan Filsafat Ilmu dalam Pengembangan Ilmu Agama Islam: Menuju Kualitas Sarjana Muslim

\section{Problem Agama Islam dan Urgensi Filsafat Ilmu}

Filsafat ilmu (philosophy of science) itu dapat diharapkan sebagai pencerahan interpretatif dari berbagai solusi atas berbagai bentuk persoalan yang muncul di tengah kehidupan masyarakat, terlebih pemahaman dalam agama Islam secara komprehenship bagi para pemeluk, atau bahkan para 
sarjananya. Berkaitan dengan berbagai kesulitan dan kegalauan masyarakat, secara ringkas telah digambarkan $\mathrm{M}$. Hasan sebagai berikut:

Datangnya millinium baru membawa serta tantangan-tantangan baru yang bersifat negatif dari arus globalisasi dan krisis lingkungan hidup. Jika tidak diwaspadai akan membuat seluruh planet bumi hancur.Tambahan pula ancaman lama perang nuklir, berbagai konflik internasional yag belum terpecahkan di Timur Tengah dan Eropa Timur, perang antar suku di Afrika, penderitaan AIDS, semakin bertambahnya kejahatan dalam berbagai bentuknya, rusaknya kelembagaan keluarga, penyalahgunaan obat, kerusakan kehidupan kota, dekadensi moral dan berbagai penyakit sosial lainnya. Agama-agama yang mengajak perdamaian, keadilan, kesejahteraan hidup secara utuh-menyeluruh dan kehidupan yang baik harus menanggapi isu-isu tersebut di atas, sementara ia terus menentang ketidakadilan sosial, penindasan, korupsi, penyalahgunaan kekuasaan, keserakahan, materialisme, rasisme, seksisme, hidonisme, dan nihilism (Kamal, 2001: 51).

Pernyataan di atas, dapat dipahami betapa banyak problematika sosial masyarakat yang secara otomatis ada dan berkaitan dengan agama Islam. Di samping itu, filsafat ilmu memiliki.arti yang sangat penting terhadap pengembangan ilmu pengetahuan. la memiliki kadar keterlibatannya dengan berbagai bidang ilmu lainnya, tidak terkecuali agama Islam. Asumsi dasar ini berpedoman pada penuturan M. Amin Abdullah sebagai berikut:

llmu apapun yang disusun, diajarkan dan disebarluaskan secara lisan maupun tulisan meniscayakan paradigma kefilsafatan. Asumsi dasar seorang ilmuwan berikut metode (proses dan prosedur) yang diikuti, kerangka teori, peran akal, tolok ukur validitas keilmuan, prinsip-prinsip dasar, hubungan subyek dan obyek merupakan beberapa hal pokok yang terkait dengan struktur fundamental sebuah bangunan keilmuan, seperti ilmu-ilmu kealaman, sosial, humaniora, agama (ulumuddin), studi agama (religious studies), maupun ilmu-ilmu keislaman (Abdullah, 2001: 366).

Barangkali, ketika kita melihat berbagai kajian wilayah studi Islam (Islamic studies), maka perlu dijelaskan kajian wilayah kerja filsafat ilmu 
(philosophy of science) itu dibutuhkan adanya titik sentral yang perlu dipertimbangkan sebagaimana konsep kerangka teori pokok persoalan. Selanjutnya, dalam konteks kerangka teori ini, urgenitas filsafat ilmu (philoshophy of science) sangat dibutulikan (Abdullah, 2001: 268).

Berkenaan dengan hal tersebut di atas, sesungguhnya filsafat ilmu tidak dapat berdiri sendiri. Ia perlu berdiskusi dengan sosiologi ilmu pengetahuan, dikarenakan adanya korelasi dengan era post positivistic ini. Pada dasarnya, bahwa tidak ada satu bangunan keilmuan dalam wilayah apapun, termasuk di dalamnya wilayah agama, yang terlepas dan tidak terkait sama sekali dengan persoalan kultural, sosial, dan bahkan sosial politik yang melatarbelakangi kemunculannya (Fadil, 2004: 52).

Melihat realitas di lapangan, persoalan yang muncul adalah para pengajar di Perguruan Tinggi Islam kurang begitu tertarik untuk memahami asumsi dasar, kerangka teori, paradigma, epistemologi, dan struktur fundamental keilmuan yang melatari dibangunnya ilmu tersebut ratusan tahun yang silam. Sebagai salah satu jawabannya adalah karena belum begitu banyak buku disusun khusus untuk kajian tersebut. Di samping itu, wilayah kajian filsafat dan epistemologi keilmuan studi Islam memang sengaja dihindari pembahasannya. Karena wilayah yang bersifat konseptual filosofis ini lebih rumit dan lebih pelik pembahasannnya dari pada ilmu-ilmu praktis yang telah jadi dan mapan. Bahkan bukan rahasia lagi, bahwa diskusi filsafah pada umumnya, terlebih filsafat ilmu sangat dihindari oleh para faqih dan teolog (Al Jabiry, 1990: 497-8). Selanjutnya, pengkajian dalam wilayah Islamic studies banyak dihadapkan berbagai bentuk persoalan (baca: pemahaman dan pengertian ajaran lslam). Sesungguhnya, ada dua tradisi berfikir keilmuan dalam Islamic studies, pertama tradisi berfikir keilmuan secara konvensional pada abad ke-10 sampai ke-11, kedua, tradisi keilmuan secara kontemporer dengan memanfaatkan kerangka teori, sebuah metodologi yang digunakan oleh ilmu-ilmu sosial dan humanities dan berkembang sekitar abad ke 18-19 (Abdullah, 2002: 4).

Mohammed Arkoun, sebagaimana yang kita pahami pernah mempertanyakan dengan tegas tentang menghilangnya dimensi historisitas 
dari keilmuan fiqih dan kalam. la juga' mempertanyakan keabsahan pengekalan teori-teori, fiqih, kalam, dan tasawuf yang sudah disusun sejak berabad-abad yang lalu untuk diajarkan terus menerus pada era sekarang setelah munculnya berbagai tantangan dan permasalahan zaman yang senantiasa berubah di tengah kehidupan masyarakat sebagaimana era sebelumnya (Arkoun, 1986: 172-3). Pernyataan ini, merupakan reaksi dari tradisi berfikir keilmuan yang mempertahankan kekakuan dan kemapanan di antara kalangan ushuliyyun, fuqaha', atau bahkan mutashawifun.

Dari dua kutub di atas, apabila bertemu, berdialog, berdiskusi, maka persoalan yang berkaitan dengan kerangka teori, metodologi, dan epistemologi yang digunakan pun berubah. Hal ini juga sejalan dengan konsep Fazlur Rahman yang merespon keberadaan usul fiqih, maupun fiqih dalam konteks syari'ah yang selama ini cenderung terhadap kemapanan. Ia menandaskan bahwa sesungguhnya, kerangka teoritik yang digunakan tidak lagi cukup memadai untuk menggunakan teori fiqih atau usul fiqih yang biasa sangat populer di kalangan usuliyyun dan fuqaha' yaitu qath'iyyat dan dzanniyyat. Ia berusaha telah memodifikasinya dalam formula ideal moral al Quran dan legal spesifik fiqih dan syari'ah (Rahman, 1982: 13-42).

Adalah benar, bahwa sejalan dengan bergulirnya era kontemporer saat ini, Muhammad Syahrur mempertanyakan melalui hasil karyanya al Kitab wa al Quran tentang akurasi analisis dan kerangka keilmuan Islam klasik jika harus diterapkan seluruhnya pada era kontemporer (Syahrur, 2003: 112). Keberadaan model cara berfikir Muhammad Syahrur ini merupakankeunikan tersendiri dalam kerangka menemukan konsep pemahaman dalam mengkaji studi Islam di lingkungan para sarjana muslim. Persoalan yang muncul, tidak dapat dipisahkan dari latar belakang proses perjalanan intelektual beliau bahwa, model pemikiran yang ditawarkan dapat menghentakkan hati sejumlah para sarjana Muslim, karena pengaruh kebarat-baratan. Pemikiran tersebut, ada benarnya karena proses perkembangan pemikirannya banyak diwarnai oleh berbagai ide Marxisme ketika ia sedang melanjutkan ke Moskow, sekalipun secara formal ia tidak mengklaim sebagai penganut faham materialisme (Sadzali, 2001: 15). 
Memperbincangkan model tradisi pemikiran kontemporer, pada kenyataannya di lingkungan masyarakat terdapat dinamika pemikiran yang cukup signifikan. Sebagaimana yang kita lihat dalam konteks pemikiran aktivis-aktivis gender termasuk di antaranya Amina Wadud dan Muhsin, Riffat Hasan, Fatima Mernissi dan lain-lain, yang telah mempertanyakan keabsahan berbagai hadits missoginik atas dasar pendekatan analisis gender. Sekarang apabila usaha analisis para aktivis benar-benar disosialisasikan di tengah berbagai lini kehidupan mayarakat secara formal maupun non formal, dan masyarakat benar-benar menerima konsep analisa gender yang ditawarkan, maka akan dapat membuahkan dampak yang sangat luas. Terutama secara khusus di kalangan komunitas muslim kontemporer yang berkenaan dengan keilmuan hukum Islam, dan ilmu-ilmu agama lainnya, berikut secara umum di kalangan komunitas non muslim dengan berbagai persoalan ilmu sosial.

Selanjutnya, sesungguhnya ajaran Islam memiliki konsep yang nyata baik konsep al Quran maupun al Sunnah tentang pengetahuan. Para penganut agama Islam memiliki konsistensi yang cukup signifikan dalam upaya untuk menggali substansialisme nilai-nilai dalam ajaran itu. Akhirnya, Islam memiliki konsep besar yang patut diperhitungkan dalam kancah dinamika keilmuan dan peradaban dunia.

Melihat di tengah kehidupan masyarakat dunia, ada sesuatu keharusan yang perlu dicatat dalam sejarah perjalanan umat manusia, bahwa sesungguhnya Islam diposisikan pada tempat yang sangat penting dan menjadi referensi perkembangan ilmu pengetahuan dan peradaban dunia. Pada situasi dan kondisi itulah, periodisasi awal Dinasti Bani Abasyiah, Islam mengalami kejayaan yang tidak dapat tertandingi oleh siapapun dan negara manapun termasuk Barat. Penjelasan ini, pada tataran teoritis-praktis dalam Islam sejalan dengan pedoman yang diyakini kebenaran oleh para pemeluknya. Namun demikian, periode selanjutnya, respon umat Islam terhadap ilmu pengetahuan sudah tidak diperhitungkan oleh negara-negara dunia, dan posisi kejayaan Islam itu diambil alih oleh negara-negara barat. Akibat peristiwa tersebut, Islam tidak dipandang lagi sebagai teori yang dapat 
menjelaskan berbagai bentuk persoalan yang berkembang di masyarakat, akan tetapi hanya dipandang sebagai doktrin dan justifikasi atau bahkan agama belaka.

Dari berbagai uraian di atas, para sarjana Muslim ingin mencoba dan berusaha membuka pintu untuk dapat metekonstruksi berbagai kejanggalan dan problematika umat Islam dan dapat mencarikan solusi kembali untuk membangkitkan kejayaan umat Islam melalui berbagai pendekatan, baik itu teologi, sejarah, sosial, antropologi, agama, filsafat dan lain-lain. Penggunaan filsafat ilmu inilah, termasuk sebagian metode untuk mengembangkan agama Islam dalam konteks epistemologis nya, sebagaimana simantika bahasabahasa agama yang sering muncul dan memiliki makna variatif, berikut proses metodologi yang dipergunakan dalam memahami dan memecahkan problematika melalui pendekatan agama itu sendiri. Sehingga dengan demikian, agama Islam itu selalu eksis dan dapat didialogkan atau dapat menjadi rujukan di tengah kehidupan masyarakat.

\section{Esensi Filsafat, dan Filsafat Ilmu}

Ada sejumlah pakar filsafat yang menjelaskan tentang pengertian filsafat ilmu, diantaranya dikemukakan bahwa filsafat ilmu itu adalah sebagai kelanjutan dari perkembangan ilmu pengetahuan (Wibisono, 2003: 45). Menurut pendapat beliau secara etimologi disebut sebagai Wissenschaft lehre, Philosophy of Science, Wetenchopleer biasa diterjemahkan sebagai filsafat ilmu. Melihat secara terminologi, filsafat ilmu adalah sebagai refleksi falsafati yang tidak mengalami titik henti dalam meneliti hakekat ilmu menuju pada sasarannya, yaitu apa yang disebut sebagai kenyataan atau kebenaran, sasaran yang memang tidak pernah habis difikirkan dan tidak pernah selesai diterangkan.

Pengertian filsafat ilmu tersebut, akan lebih mudah dapat dipahami apabila kita memahami dan mengerti tentang pengertian filsafat itu sendiri. Selanjutnya, beliau sebagai seorang guru besar filsafat ilmu mengemukakan bahwa filsafat adalah suatu upaya manusia, suatu pengembaraan intelektual yang tak pernah mengenal titik akhir dalam mencari dan menemukan 
kebenaran atau kenyataan (Wibisono, 2003: 1-6). Kebenaran atau kenyataan itu sendiri bukanlah barang jadi yang sudah selesai, berhenti dalam kebekuan dogmatis dan normatif, melainkan sesuatu yang terbuka. Di samping itu, beliau juga mengutip tentang penjelasan filsafat ini dari pendapat Fichte (1762-1814) seorang tokoh dalam aliran filsafat spekulatif-idealisme Jerman di zaman filsafat modern, yang di kutip dari karya A. Vloemans (1948) Leven en Leer der Grote Denkers. Bahwa filsafat adalah hasil keseluruhan kepribadian kita masing-masing, sehingga filsafat apa yang kita pilih bergantung kepada siapa dan bagaimana kita ini. Suatu sistem filsafat bukanlah benda mati yang begitu saja dapat kita ambil untuk kemudian kita berikan kepada orang lain dengan sesuka hati kita. Filsafat itu merupakan sesuatu yang dijiwai oleh siapa dan bagaimana keyakinan seseorang. Filsafat akan selalu berkembang karena manusia dalam hidup dan kehidupannya juga akan terus menerusberkembang (Wibisono, 2003: 1-3).

\section{Makna Ilmu dalam Prespektif Islam}

Memperbincangkan filsafat ilmu tidak dapat dipisahkan dengan filsafat dan ilmu, karena sesungguhnya sasaran obyeknya adalah ilmu pengetahuan itu sendiri. Selanjutnya, apabila pemahaman filsafat ilmu itu ditangkap, secara logika juga dapat memahami pengertian ilmu secara umum.

Berbagai argumentasi tentang ilmu dalam al Quran maupun as Sunnah banyak sekali, atau bahkan disebutkan kata jadian "al llmu" dalam al Quran terhitung kuranglebih sebanyak 780 kali. Namun demikian, perlu diketahui ayat yang pertama kali diturunkan Allah SWT. justru tentang urgensitas membaca, pena, dan ajaran untuk manusia (QS. al 'Alaq: 1-5), penciptaan Adam, dan perintah terhadap malaikat untuk bersujud kepada Adam setelah beliau diajari nama-nama (QS. al Baqaarah: 31-32). Hanya orang-orang yang balajarlah yang memahami (QS. al Ankabuut: 43), perbedaan orang-orang yang berilmu dan orang-orang yang tidak berilmu (QS. az Zumar: 43), orangorang yang takut kepada Allah (QS. al Faathir: 28).

Berbagai ayat di atas, menjelaskan bahwa kata 'ilm, pengetahuan, sains, knowledge, sebagaimana kata eksistensi (wujud) mempunyai rangkaian 
makna luas yang berbeda dari sudut pandang kekuatan atau kelemahan, kesempurnaan atau kecacatan. Makna generik ini mengandung spektrum arti yang telah digunakan di dalam sunnah Nabi. Selanjutnya, pengertian luas 'ilm dapat digunakan makna-maknanya secara bervariasi. Hal ini dimaksudkan, untuk menetapkan bahwa pada tataran (tingkat) 'ilm apa pun seseorang harus berjuang untuk mengembangkannya lebih jauh. Kewajiban mencari ilmu yang disebutkan dalam hadits Nabi tersebut diarahkan kepada para setiap muslim, ilmuwan, orang bodoh, ataupun pemula. Mereka itu dapat digambarkan sebagaimana anak kecil yang berangkat dewasa, ia senantiasa memahami, mengkaji ilmu apa pun yang sebelumnya belum ia ketahui.

Pengertian 'ilm yang didasarkan dalam konteks Islam terpolarisasikan dalam dua hal berupa 'ilm al-ghaib wa al-syahadat, artinya ilmu yang tampak dan ilmu yang tidak tampak. Sesungguhnya, penafsiran di atas merupakan pendapat ahli tafsir yang memahami Islam secara normatif, akan tetapi pemahaman penafsiran ahli tafsir kontemporer mengatakan bahwa ilmu Islam yang tidak tampak, dapat diartikan ilmu yang tampak/nyata/materi, hanya saja, pengetahuan yang ada di kalangan umat Islam belum dapat menembusnya, yang termasuk di antaranya, M. Syahrur .

Pada dasarnya, kata 'ilm dalam pandangan Islam dapat melahirkan ilmuwan, 'alim, atau bahkan Ulul Albab, yang dikaji secara jelas dalam QS. Ali Imran: 190-191. Penggunaan istilah 'alim, ilmuwan mencakup potensi dasar berupa dua hal yang meliputi, dzikir (spiritualitas) dan fikir (intelektualitas), selanjutnya, dari penggabungan dua konsep itu akan dapat melahirkan 'amal shalih (profesionalitas). Penjelasannya, konsep dzikir akan digunakan untuk menghadapi problematika yang bersifat ke Tuhanan (transcendental), sedangkan konsep fikir akan dapat berperan sebagai pisau analisis untuk menjawab berbagai persoalan materi dan kosmos secara empiris yang berkembang. Selanjutnya, perpaduan antara dua konsep tersebut menghasilkan 'amal saleh (profesionalitas), dan orang-orang yang professional yang disebut Ulul Albab.

Dari penjelasan di atas, konsep 'ilm, sains, knowledge dalam pandangan Islam setelah dikaji secara detil tidak lagi dipahami ada dikotomi ilmu, 
yang selama ini diikuti oleh sebagian pemikir yang masih cenderung mempertahankan penafsiran secara tekstual, temporal, lokalitas, dan sesaat. Akan tetapi konsep 'ilm dalam pandangan Islam yang mencakup pemikiran rasional, empiris, dan logis melalui (al fikr)di satu sisi, berikut pemikiran secara intuitifimajinatif, dan metafisis melalui (al dzikr) pada sisi yang lain.

Perpaduan dua hal tersebut, sesungguhnya akan dapat melahirkan berbagai aktivitas (produk) yang signifikan, dapat dipahami dalam bahasa Islam, biasa disebut dengan amal shalih (profesionalitas). Sehingga berbagai hasil (produk) yang didapatkan bisa bersentuhan secara langsung maupun tidak langsung dengan hal-hal yang bersifat material maupun immaterial.

Bertolak dari keterangan di atas, sesungguhnya dapat melahirkan perbedaan antara produk intelektual muslim yang memiliki pemikiran rasional-empiris-logis dan, pemikiran intuitif imajinatif metafisis. Keduanya diarahkan pada tataran material al Syahadat (fisik), maupun tataran immaterial al Ghaib (psikis), dengan produk intelektual Barat yang hanya diarahkan pada material al Syahadat (fisik) saja.

\section{Kondisi Ilmu di Tengah Perkembangan Masyarakat}

Ada dua hal yang dapat diangkat dalam konteks kajian ini pertama, ilmu dalam perspektif historis dan kedua ilmu dalam perspektif sosiologi 1. Ilmu dalam Historis

Perkembangan ilmu dalam Islam memiliki signifikansi historisitas yang menarik. Islam pernah dijadikan pusat peradaban dan kebudayaan dunia yang merupakan bukti nyata, karena sesungguhnya, universalisme etos kerja yang dimiliki umat Islam yang sangat menghargai ilmu pengetahuan dapat dijaga dan dipertahankan. Pengetahuan tentang historis kejayaan ilmu pengetahuan Islam dapat ditemukan oleh sejarawan ilmu pengetahuan modern, Kneller, yang dapat dikemukakan sebagai berikut (Majid, 1997: 15):

(a). Sebagian besar temuan ilmiah dari seluruh bangsa di dunia, telah diserap oleh Islam yang sejak $750 \mathrm{M}$ sampai abad pertengahan

Ulul Albab, Vol. 10, No. 1, 2009 
terbentang, dari Spanyol sampai Turkistan. Dalam hal ini bangsa Arab (Muslim) telah menyatukan kumpulan ilmu pengetahuan yang luas dan mengembangkannya

(b). Ketika ilmu pengetahuan Arab mundur, dari antara ketiga peradaban besar yang mengelilingi Islam-Cina, India, dan Eropa, justru Eropa yang mewarisi sintesanya yang agung. Hal ini disebabkan karena pada tahun $1000 \mathrm{M}$ Eropa begitu mundurnya sehingga harus meminjam ilmu pengetahuan Islam dengan menerjemahkan karya-karya Arab ke bahasa Latin

Periode selanjutnya, perputaran roda kendali kejayaan ilmu pengetahuan Islam yang berpegang nilai-nilai Islam (al ghaibi wa al syahadat) berubah menjadi ilmu pengetahuan yang dipegang dan dikendalikan oleh sainstis-sainstis Barat. Akhirnya, ilmu pengetahuan yang dikembangkan itu ada semacam indikasi pemisahan antara ilmu dan agama (sekularisasi). Meskipun perkembangan ilmu pengetahuan di Barat itu mau tidak mau senantiasa mendapatkan pengakuan dunia saat ini atas segala kesuksesan dan keberhasilannya. Pengakuan contribution of knowledge Barat tidak sedikit yang sejalan dengan konsep ilmu pengetahuan dalam Islam.

2. Ilmu dalam Perspektif Sosiologi

Perkembangan ilmu pengetahuan tidak dapat dipisahkan dengan filsafat, sebab sasaran (objek) filsafat itu ilmu pengetahuan. Umat Islam serelah mengalami pergeseran nilai dari masa kejayaannya, mulai tampak kesadaran untuk membangkitkan kembali urgensitas epistemologi yang selama ini hilang di permukaan.

Ketika umat Islam kehilangan dasar epistemologinya, semangat merespon perkembangan berbagai bentuk persoalan di masyarakat berkurang. Penggalian keilmuan yang baru, pengadaan penelitian, pemahaman teksteks al Quran maupun al-Sunnah diabaikan, atau bahkan memahami substansialisme nilai-nilai ajarannya cenderung apriori, apologitik, dan eksklusif. Kurang adanya interaksi dan dialog dengan filsafat, maupun ilmuilmu baru yang berkembang. Perjalanan selanjutnya, orang-orang Islam dalam 
proses pengembangan keilmuan mereka hanya sebatas pembacaan teks-teks yang ada, penghafalan, dan pengamalan ritual-ritual keagamaan.

Umat lslam sendiri pada saat sekarang ini, mulai berlomba-lomba untuk membangunkan kesadaran diri yang selama ini terpendam. Terutama membuka pintu dalam konteks pemahaman ajarannya, sebagaima mereka digerakkan oleh sebuah konsep tauhid (teologi) dengan secara inklusif, igaliter, dan kebebasan. Meskipun kebebasan yang dimaksudkan tidak persis sama seperti dipahami oleh orang-orang Barat saat ini.

Asumsi dasar di atas, sesungguhnya yang dapat menggugah dan menggerakkan para ilmuwan muslim untuk membangun kesadaran ilmiah itu. Inklusifitas mereka dapat melahirkan interaksi, dialog, dan bersentuhan dengan berbagai pendekatan, yang biasa dipakai orang-orang non muslim sekalipun. Berbagai pendekatan tersebut, diantaranya pendekatan teologis, sosiologis, empiris, historis, antropologis, positivistis, dan lain-lain.

\section{Upaya Menuju Pengembangan Agama Islam}

Bertolak dari para cendikiawan muslim (Ulul Albab) yang memiliki semangat keilmuan, maka dapat disadari tentang urgensitas ilmu pengetahuan. Mereka memiliki komitmen bersama membuka pintu untuk membangun kesadaran dari ketertutupan, keterpurukan, kebelengguan intelektual dalam kerangka mewujudkan kembali masa kejayaan umat Islam di masa abad yang silam.

Para cendikiawan muslim setelah mengalami tradisi pemikiran konvensional pada abad ke-10 dan ke-11, hanya terfokus dan terkonsentrasi oleh pemikiran yang terjebak pada tataran dogmatisteologis. Mereka memiliki agenda aktifitas dalam kerangka transformasi keilmuan sudah merasa nyaman, nikmat dan merasakan kebebasan terhadap beban, atau bahkan problem yang menjadikan suatu keharusan tanggungjawabnya. Perkembangan selanjutnya, proses transformasi ilmu pengetahuan yang dikembangkan di permukaan, hanya sebatas membaca teks-teks yang ada, menghafal, dan mengamalkan ritual-ritual keagamaan dalam kehidupan keseharian. Tradisi pemikiran tersebut, masih diwarisi dan sangat dirasakan kental dalam konteks kehidupan masyarakat kita.

Ulul Albab, Vol. 10, No. 1, 2009 
Melihat situasi dan kondisi seperti itulah, sejumlah ilmuwan muslim mempunyai obsesi yang sangat kokoh melakukan dekonstruksi-rekonstruksi dalam membangun kerangka teori berfikir filosofis-metodologis-empiris dalam pola pengembangan keilmuan mereka. Sehingga kekakuan, kebekuan dan kejumudan yang terdapat dalam diri mereka selama ini dirasakan, dapat dicairkan secara signifikan.

Semangat yang mereka bangun sesungguhnya, didasarkan atas historisitas, tanggung jawab sebagai ilmuwan, dan kesadaran yang sangat tinggi. Pada dasarnya, hal ini dimulai munculnya sejumlah para cendikiawan muslim sebagaimana Mumammad Arkoun dalam karyanya, Tarikhiyyah al Fikr al Araby al Islamy, Nasr Muhammad Abu Zaid dalam karyanya, Naql al Kitab al Diny, Richard C. Martin dalam karyanya, Apoproachess in Islam Religious Studies. Pernyataan-pernyataan di dalamnya secara tegas mengemukakan bahwa polarisasi dua pemikiran antara tradisi pemikiran konvensional pada (abad ke-10-11) dan tradisi pemikiran kontemporer pada (abad ke-18-19) dapat melakukan saling dialog-interaktif, pendekatan, dan bersentuhan sedemikian rupa, sehingga berbagai problematika yang berkembang di permukaan dapat diminimalisasikan, dicairkan, atau bahkan diselesaikan scara proporsional, baik itu agama, politik, ekonomi, sosial, maupun budaya, dan lain-lain.

Proses penyelesaian berbagai problematika tersebut, mengundang bangunan pemikiran falsafati, epistemologi, asumsi dasar, kerangka teori, paradigma, metodologi, dapat dikolaborasikan dengan berbagai disiplin ilmu lainnya sebagaimana sosiologi, ekonomi, politik, maupun budaya, dan lain-lain. Penjelasan yang dimaksud, sesungguhnya senada dengan kutipan M. Amin Abdullah dari Ebrahim Moosa dalam sebuah pengantar karya Fazlur Rahman, Revival an reform in Islam: A. Study Islamic Fundamentalism, sebagaimana berikut:

Setelah mengungkap berbagai persoalan terkait dengan hubungan internasional, politik dan ekonomi. Hal demikian bahwa ilmuwan dan ahli-ahli agama (termasuk didalamnya ahli-ahli ilmu keislaman) harus juga menjadi ahli ekonomi dan ahli politik. Namun demikian, studi agama

Ulul Albab, Vol. 10, No. 1, 2009 
(termasuk di dalamnya studi Islam) akan mengalami kesulitan berat-untuk tidak menyebutnya menderita jika pandangannya menyadari dan tidak mempertimbangkan bagaimana wacana yang berkembang dalam politik, ekonomi dan budaya berpengaruh terhadap penampilan dan perilaku keagamaan dan begitu pula sebaliknya (Abdullah, 2001: 18).

Melihat peta pentransformasian ilmu pengetahuan yang dikembangkan oleh para ilmuwan muslim kita, sedikit banyak mulai ada indikasi-indikasi yang melahirkan kesuksesan dan keberhasilan yang dapat mewarnai dan mempengaruhi realitas percaturan keilmuan di dunia ini. Fragmentasi realitas mode of tought dan contribution of knowledge dapat dilihat sebagaimana yang selain disebutkan di atas, seperti: Hasan Hanafi dengan oksidentalismenya, Muhammad Abed al Jabiri dengan post tradisionalismenya, Fazlur Rahman dengan neo-modernismenya, Muhammad Syahrur dengan marxismenya, Ali Ashghar Engeneer dengan egaliterianismenya, al Naquib al Attas dengan filsafat Islamnya, atau bahkan di kalangan muda Indonesia mencoba menemukan teori barunya yaitu Islam liberalnya, dan lain-lain.

Berbagai produk intelektual mereka itu didasarkan oleh kemampuan bangunan kerangka berfikir secara sistem ilmiah, yang mempunyai corak pemikiran kritis, analitis, dan obyektif, dalam merespon berbagai persoalan yang berkembang di tengah kehidupan di masyaräkat. Di sisi lain, mereka juga berusaha untuk bersentuhan, berdekatan, berinteraksi dengan bangunan epistemologi Barat sedemikian rupa. Sehingga mampu mengelaborasikan teori-teori Barat dengan teori-teori Islam. Dengan perpaduan dua titik sentral keilmuan tersebut, akhirnya dapat menghasilkan teori-teori baru yang bisa disosialisasikan di tengah permukaan secara signifikan.

Berangkat dari representasi para ilmuwan muslim di atas, ada sebagian di antaranya yang perlu dijelaskan sebagai corak teori baru yang mereka miliki. Hal ini, di antaranya sebagaimana yang dilontarkan Muhammad Arkoun yang mendekonstruksi nalar agama dan nalar modern. la menggugat dalam horizon ortodoksi Islam, yang merupakan otoritas al Quran dengan interpretasi tunggal sebagai sumber seluruh bangunan Islam yang relevan dengan tuntutan situasi dan kondisi, tanpa adanya dialog-interaktif dengan dinamika keilmuan di 
dunia. Otoritas ini juga diperkuat dengan posisi hadits sebagai rujukan penjelas al Quran dalam satu sisi, dan dari sisi lain. la juga menggugat nalar yang dikembangkan materialisme, sosialisme, dan modernisme.

Dalam merealisasikan pernyataannya di atas, setidaknya ada tiga langkah strategis yang dilakukan (Arkoun,1993: 75). Pertama, pemilihan metodologi yang tepat untuk membongkar sejarah ortodoksi turats Islam. Pendekatannya filologi, linguistik, psikologi, sosiologi, antropologi, ontologi, dan semiotik. Kedua, kritik terhadap arogansi kodifikasi mushaf Utsmani sebagai produk sejarah manusiawi yang melenyapkan kekayaan siyaq al Quran. Hal ini berdampak pada tertutupnya pola-pola kebahasaan sebagaimana diujarkan kali pertama. Ketiga, pola pemahaman terhadap al Quran dengan penjelajahan sinkronis yang meliputi kajian linguistik, antropologis, semiotik, sosiokritik, psikokritik, dan historis. Hal ini, juga sejalan dengan Fazlur Rahman, yang ingin mencoba melakukan berbagai interpretasi yang secara luas dalam merespon berbagai persoalan yang berkembang, terutama berbagai interpretasi subyektifitas yang selama ini dipertahankan, di samping ketertutupan, dan kebekuannya tanpa sedikitpun mempedulikan proses dialogis-historis manusia (Rahman, 1984: 118).

Sebagaimana halnya di atas, Muhammad Abed al Jabiri juga menawarkan berbagai pendekatan yang cukup signifikan dalam upaya kualitas pengembangan dalam proses transformasi keilmuan Islam, pendekatan tersebut diantaranya, objektifitas (madhu'iyyah), historisitas (tarikhiyyah), dan kontinuitas (istimrariyyah). Selanjutnya, penerapan konsep obyektifitas dimaksud, akan dapat melahirkan semangat netralitas antara pengkaji (subjek) dan kajiannya (objek). Sedangkan penerapannya melalui historisitas dan kontinuitas, dapat difragmentasikan dalam konteks al fasl, dan al wasl. Artinya, menghubungkan antara pengkaji (subjek) dan kajiannya (objek), berikut, memisahkan pengkaji (subjek) dan yang dikajinya (objek). Penjelasan tentang al fasl penghubungan dan pemisahan al wasl dapat diartikan juga sebagai penempatan kajian kritis filosofis, dan sebagai penyelesaian atas problematika yang muncul. 


\section{Simpulan}

Memahami dari berbagai uraian di atas, maka dapat disimpulkan bahwa:

Konsep sain (' $\mathrm{llm}$ ) memiliki dua pengertian sebagai berikut: pertama, al fikr (pemikiran) dan kedua, al dzikr (spritualitas). Hasil dari integrasi dua konsep di atas dapat melahirkan amal saleh (profesionalitas).

'Para Särjana Muslim dengan kerangka bangunan epistemologi dan exiologisnya dapat mejadikan perubahan yang berarti dalam memahai nilai-nilai Islam yang sesuai dengan tuntutan zaman. Pemikiran dari keterbelakangan, kejumudan, kebekuan dapat berubah menjadi interaktif, dialogis mereka yang signifikan dengan saintis-saintis Barat dan lain-lain.

Banyak Sarjana Muslim yang bermunculan, yang berarti pula membuahkan indikasi-indikasi keberhasilan mereka dalam merekonstruksi pemikiran Islam di tengah kehidupan masyarakat. Hal ini dapat kita lihat dalam karya-karya monumental mereka yang selalu sejalan dengan kepentingan umat Islam. 


\section{Daftar Pustaka}

Abdullah, M. Amin. 2001. AlTa'wil al 'llmi: Kearah Perubahan Paradigma Penafsiran Kitab Suci. Yogjakarta: al Jami'ah.

Abdullah, M. Amin. 2002. Profil Lulusan Berbasis Kompetensi AkademikIntegralistik Program Pasca Sarjana Perguruan Tinggi Islam dalam Era Masyarakat Berubah.Yogjakarta: Institut Agama Islam Negeri (IAIN) Sunan Kalijaga.

Abid al Jabiry, Muhammad. 1990. Bunyah al'Aql al'Araby Dirasah Tahliliyah Naqdiyyah li Nudzumi al-Ma'rifah fi al-Thaqafah al'A Arabiyyah. Beirut: Markaz Dirasah al Wihdah al 'Arabiyah.

Syahrur, Muhammad. 2003. Rekonstruksi Konsep Wahyu. Terjemahan oleh Achmad Syarqawi Ismail. Tt. Yogjakarta: el-SAQ Press.

Arkoun, Muhammad. 1993. Alfkr al-Ushuli wa Istihalah al-Ta'shil Terjemahan oleh Hashim Shaleh. Beirut: Dar al-Saqi.

Arkoun, Muhammed. 1986. Al Islam: al-Akhlaq wa al-Siasah. Beirut: Markaz al Inma' al Qoumi.

Fadil SJ, 2004. Revitalisasi Filsafat Ilmu Bagi Pengembangan Keilmuan di UIN, dalam M. Zainuddin, dkk., (Eds.), Memadu Sains dan Agama Menuju Universitas Islam Masa Depan. Malang: Kerjasama UIN Malang dan Bayumedia Publisihing.

Fawaid Sadzali, Ahmad. 2001. Dekonstruksi Studi Ilmu al Quran: Telaah atas Ancangan Hermeniutika Kitab Suci Muhammad Syahrur. Skripsi. Jakarta: Fakultas Syarif Hidayatullah.

Fuadi Abdu al Baqi', Muhammad. Tt. Al Mu'jam al Mufahras Li al Fadi al Quran. Indonesia: Maktabah Dahlan.'

Kamal, M. Hasan. 2001. The Expanding Spiritual-Moral Role of World Religions in the New Milienium. Tt. American Journal of Islamic Sosial Sciences.

Majid, Nurcholis. 1997. Kaki Langit Peradaban. Jakarta: Paramadina. 
Rahman, Fazlur. 1982. Islam dan Modernity: Transformation of intellectual Tradition. Chicago dan London: The University of Chicago Press.

Rahman, Fazlur. 1984. Membuka Pintu ljtihad. Terjemahan oleh Anas Mahyuddin. Bandung: Pustaka.

Syahrur, Muhammad. 1990. Al-Kitab wa al-Quran. Dimasq: Qira'ah Mua'sirah.

Wibisono, Koento. 2003. Pengertian Tentang Filsafat dalam Perkuliahan S-3 pada Program Pasca Sarjana IAIN Sunan Ampel Surabaya. Surabaya: PPS IAIN Sunan Ampel. 